\title{
Field Performance Evaluation of Push Type Prilled Urea Applicator in Rice Cultivation
}

\author{
A K M Saiful Islam, M A Rahman ${ }^{1}$, A K M Lutfor Rahman'1, M T Islam¹ and M I Rahman ${ }^{1}$
}

\begin{abstract}
BRRI prilled urea applicator was designed and developed to facilitate deep placement of regular urea. Experiments were conducted to evaluate the performance of BRRI prilled urea applicator in the farmers' fields at Gosaidanga in Shailkupa upazila under Jhenaidah district and at Rashidpur in Mithapukur upazila under Rangpur district during Boro 2015 season. Three treatments: hand broadcasting of urea (recommended dose) (HB), BRRI prilled urea applicator (70\% of the recommended dose) (PUA) and BRRI USG applicator (70\% of the recommended dose) (USGA) were compared in the experiments. The experiment was laid out in randomized complete block design (RCBD) and replicated in four farmers' plots in each location using BRRI dhan 28 as test crop both the locations. Prior to field experiment, prilled urea applicator was calibrated and urea dispensed was set to $14 \mathrm{gm}$ in one revolution of drive wheel for Boro season. The field capacity of the PUA and USGA was almost similar $\left(0.09-0.10 \mathrm{ha} \mathrm{hr}^{-1}\right)$ in both the locations. Field efficiency of PUA and USGA had 64-65 and 68-69 percent, respectively. PUA and USGA saved 29-32 percent urea fertilizer compared to HB whereas labour requirement of $\mathrm{HB}$ (3.74-4.04 man-hr ha-1) in three splits showed similar to single application of urea by PUA (3.68-4.00 man-hr ha-1) and USGA (3.78-3.97 man-hr ha- $\left.{ }^{-1}\right)$. Urea application cost in HB, PUA and USGA was Tk 4,624, 3,216-3,424 and 3,305-3,483 per hectare in both the locations. Prilled urea application method reduced the production cost. Urea application methods showed insignificant effect on grain yield. BRRI prilled urea safely dispensed urea fertilizer in subsurface, increased the efficacy of urea fertilizer and saved urea fertilizer without sacrificing grain yield. BRRI prilled urea applicator could be a viable technology in rice cultivation. Extensive dissemination works should be undertaken in different agro-ecological zones for wide spread adoption of the applicator.
\end{abstract}

Key words: Field capacity, fertilizer saving, labour requirement, benefit-cost ratio

\section{INTRODUCTION}

Nitrogen is one of the essential plant nutrients, which can augment the production of rice to a great extent. Prilled urea is an important source of nitrogen and application of urea-N plays a vital role in vegetative growth, development and yield of rice. A substantial amount of the urea- $\mathrm{N}$ is lost through different mechanisms including ammonia volatilization, denitrification and leaching losses, causing environmental pollution problems (Choudhury and Kennedy, 2005). The importance of the role of nitrogenous fertilizer in increasing rice yields has been widely recognized. Most of the farmers of Bangladesh apply fine urea in the rice field by broadcasting method. The efficiency of urea-N is very low, often only 30 $40 \%$ and, in some cases, even lower (Choudhury and Khanif, 2004). Yearly requirement of urea in Bangladesh is 2.9 million tons (MT) of which $80 \%$ (2.3 MT) is used for rice alone. When it is applied in at a desired depth, its application efficiency is increased to 60 percent. If all the urea could be applied in at a desired depth, then 1.15MT urea could be saved. In that case only 0.05 MT urea needs to be imported (BADC, 2011). If urea is applied in at a desired depth, a huge amount of urea production could be reduced, which in turn would save a lot of natural gas. The saved natural gas could be used to generate electricity (Bowen et al., 2005). The fine urea reduces the effectiveness of fertilizer and may lose up to $70 \%$. The losses occur in following ways: i) some of the fertilizers convert into gaseous form and mix with air, ii) some of them are dissolved with rain or irrigation water and runoff to surrounding canal and river from the applied field, and iii) even some of those go beyond the root zone of the rice plants (NAP, 2009). In the present (prilled or fine type of urea) method of application, only $40 \%$ of the applied urea is used by the plant and the remaining $60 \%$ is lost by air, water or leaching under the ground (Iqbal, 2009). 
Statistics indicated that about $80 \%$ of urea of total production is used for rice production. However, only 15 to $35 \%$ of the total applied nitrogen used by the rice plant (Prasad and Datta, 1979) and literature showed that two out of three bags of urea go unused in wetland rice production (Amit, 2011). Nitrogen loss caused due to ammonia volatilization, de-nitrification, runoff, seepage and leaching (Bhuiyan et al., 1998). Therefore, there is a great need to improve nitrogen use efficiency for rice production. Due to excessive loss of nitrogen, farmer in Bangladesh have not been able to make more efficient use of fertilizer to their rice yield. In our country, there are two types of urea i) prilled or fine type and ii) super granular type or urea super granule (USG) on the basis of size of the particles. Super granular type can be classified again as i) general granular (1.8 g) for Aman and Aus rice ii ) mega granular ( $2.7 \mathrm{~g}$ ) for Boro rice. The weight of a USG varied from 1.6-2.8g. Inserting or placing the fertilizer below the soil surface by means of any tool or implement at desired depth to supply plant nutrient to crop before or in the standing crop is called deep placement of urea. Deep placement or subsurface placement of fertilizer also ensures better distribution in the root zone and prevent any loss by surface drain-off. Much effort has been made to improve fertilizer use efficiencies in low land rice production. Deep placement of urea fertilizer into the anaerobic soil zone is an effective method to reduce volatilization loss. However, urea in the form of USG has been proved to be superior to regular urea in all aspects. It is applied in the rice field only for one time after three to four days of plantation and it contributes for the whole growing period of rice. Instead of normal doses of $247 \mathrm{~kg}$ of granular urea, only $160 \mathrm{~kg}$ of USG is required (35\% less) per hectare and it increases rice yield up to $500 \mathrm{~kg}(20 \%)$ per hectare (Iqbal, 2009). Thus using USG, the requirement of urea of the country could be reduced to 15.47 lac ton from 24.51 lac ton during 2006-07. Bangladesh Rice Research Institute (BRRI) had designed and developed a push type USG applicator during
2008 (Hossen et al., 2013). This applicator applies USG at 6 to $7 \mathrm{~cm}$ depth below the soil surface in the middle of four bunches of rice seedlings. When USG is applied by hand, 28 hours are required per hectare, whereas only 10 hours are required by the applicator. The USG applicator reduced the human drudgery. International Fertilizer Development Corporation (IFDC) has been trying to popularize the USG technology in different countries since long time. The USG technology could not be popularized at the desired level due to lack of a good applicator. From the above discussion, it is clear that USG has great impact for increasing the nitrogen use efficiency, yield of rice and its application method is also an important factor contributing to total cost of production. During operation of the USG applicator, there is a possibility to make bridge while rotating metering device due to oval shape of USG. Two USGs may drop at a time due to under size of the briquette. Besides, the USG machine would not perform satisfactory when the hopper is fully loaded. Moreover, proper size of USG was not available in the market and some percentage of urea is lost during the formation of USG. Cost of installing the USG briquetting machine was also high. To overcome these problems, in 2013, the scientists of Farm Machinery and Postharvest Technology Division of BRRI had developed the applicator to deep place prilled urea in between two rows plant in one time (Rahman et al., 2014). This machine needs to be thoroughly investigated in various agroecological zones. Therefore, the present study was undertaken with the objectives to estimate the savings of urea fertilizer and to compare the cost of applying prilled urea by applicator over USG applicator and hand broadcasting.

\section{MATERIALS AND METHODS}

This experiment was conducted in the farmers' field at Gosaidanga in Shailkupa upazila under Jhenaidah district and at Rashidpur in Mithapukur upazila under Rangpur district. The experiment was carried out in randomized complete block design (RCBD) and replicated 
in four farmers' plots (Gomez and Gomez, 1984). Twelve plots within one kilometer radius were selected to conduct this study. The treatments were $\mathrm{T}_{1}=$ Hand broadcasting of urea (recommended dose) (HB); $\mathrm{T}_{2}=$ BRRI prilled urea applicator $(70 \%$ of the recommended dose) (PUA) and $\mathrm{T}_{3}=$ BRRI USG applicator $(70 \%$ of the recommended dose) (USGA). BRRI dhan28 was grown in all the experimental plots. Seedbed preparation often involves secondary tillage by using spade and puddling was done after inundating the field. Sprouted seeds were broadcast in the field. Drainage canals were constructed for proper water removal. Puddled soil was levelled and raised to 5-10 $\mathrm{cm}$ height. Organic manure (decompose) and a small amount of inorganic fertilizer was applied as basal dressing to increase seed vigour and allows easier uprooting for transplanting. The field was prepared using common tillage practice, which is first plowing (primary tillage) once, followed puddling (secondary tillage) twice and levelling using two-wheel tractor under the flooding conditions. After first rotatilling, the field was flooded with water and kept as such for seven days and then second rotatilling was done on 8th day and the field was levelled by a plank. During final land preparation, all cares were taken for uniform levelling of the land. A fertilizer dose per hectare of $136 \mathrm{~kg} \mathrm{P}, 111 \mathrm{~kg} \mathrm{~K}$, $111 \mathrm{~kg} \mathrm{~S}$ and $11.25 \mathrm{~kg} \mathrm{Zn}$ as triple super phosphate, muriate of potash, gypsum and zinc sulfate, respectively was applied at final land preparation. Irrigation water was applied uniformly time to time as when required in all the transplanted plots for proper growth and development of crops. Maximum irrigation was needed at the panicle initiation stage. The nursery bed was made wet by application of water one day before uprooting the seedlings. The seedlings were uprooted on $29^{\text {th }}$ January
2015 without causing much mechanical injury to the roots and they were immediately transferred to the main field. Forty-five-day (for Rangpur site) and fifty-six-day (for Jhenaidah site)-old seedlings were uprooted carefully from the nursery field and transplanted in each of the well puddle unit plots on two different days. The date of transplanting was $29^{\text {th }}$ January 2015 in Rangpur site and $10^{\text {th }}$ February 2015 in Jhenaidah site. Row to row spacing of $20 \mathrm{~cm}$ was maintained but plant to plant spacing was varied. The plant to plant spacing depends largely on the skill of the labour.

\section{Calibration of PUA}

BRRI prilled applicator was designed by considering the line to line spacing of $20 \mathrm{~cm}$. Laboratory trial was done by using large granule prilled urea. Drive wheels was rotated by pouring large granule in hopper. After one revolution of drive wheel, amount of urea dispensed in both the hoppers was almost 14 gm, which satisfied the amount of urea displacement during Boro season. Fertilizer rate was varied in Aus and Aman seasons due to change in fertilizer requirement in rice crop. Before field operation, applicator was calibrated and urea dispensed was set to $14 \mathrm{gm}$ in one revolution of drive wheel for Boro season.

\section{Urea application}

Generally, hand broadcasting of prilled urea was applied in three equal splits i.e. one-third at $20 \mathrm{DAT}$, one-third at active tillering stage and one-third at 5-7 days before panicle initiation stage. The prilled urea and USG were applied by applicator at $70 \%$ of the recommended dose in one time at 2-3 days after transplanting (Photo 1a, b) 


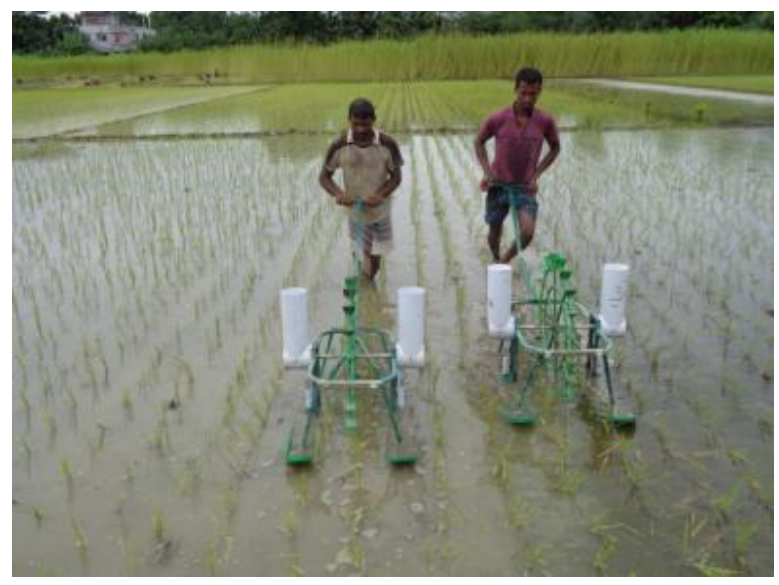

a. BRRI prilled urea applicator

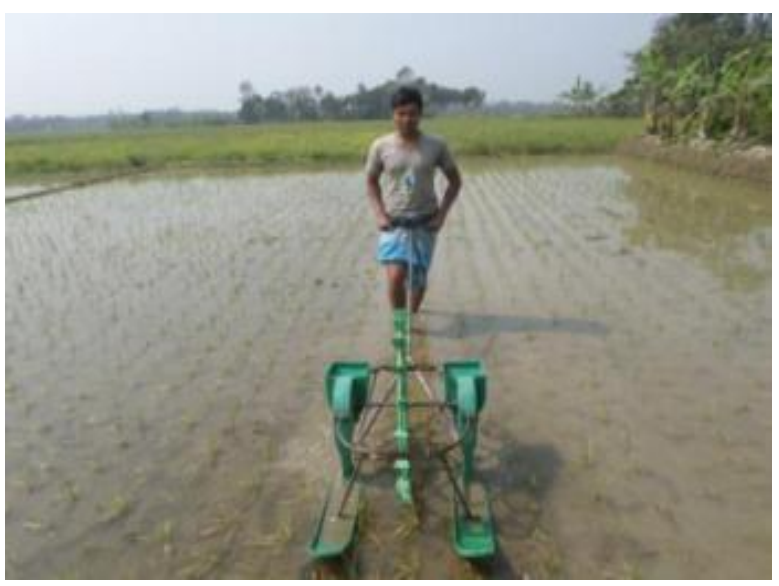

b. BRRI USG applicator

Photo 1. Fertilizer application methods

The amount of human labour involved in each operation was investigated through field measurements. As pre-planting weedicide was not applied so the weed infestation was severe and weed was controlled by hand weeding. Hand weeding was done at 30 DAT to keep the experimental plot weed free. In addition, hand weeding was done again at 58 DAT. During the Bboro season, some pest infestation was severe. However, the pests were controlled by a single application of Virtako and Nativo at the vegetative growth stage. Table 1 presents the comparative inputs of three urea application methods. Fertilizer rate was different and all other inputs were similar in three methods. Grain yield was recorded from pre-selected 10 $\mathrm{m}^{2}$ land area and adjusted moisture content of $14 \%$ moisture level. For computing above ground biomass and yield contributing characters, four hills were collected from the outside of the selected area. The dry weight of straw was determined after oven-drying at $70^{\circ} \mathrm{C}$ to constant weight. Panicle number of each hill was counted to determine the panicle number $\mathrm{m}^{-2}$. Plant samples were separated into straw and panicles. Panicles were handthreshed and the filled spikelets were separated from unfilled spikelets. Above ground total biomass was the total dry matter of straw, rachis and filled and unfilled spikelets. Spikelets per panicle, grain-filling percentage and harvest index were calculated. Border areas of all sides of the plot were excluded to avoid border competition effects. In order to estimate the production cost, the data on working speed, total time and labour involvement and materials inputs to complete the operation were recorded. Land value and interest on investment was considered to calculate the total production cost. The purchase price of the BRRI prilled urea applicator was considered as Tk 5,000 per unit. Price of the produce was collected from the local markets to compute total production cost, gross return, gross margin and benefit-cost ratio. Statistical analysis was done by using software Statistix 9.0. Least significant difference was used to compare the means. 
Table 1. Comparative input in three practices at Rangpur and Jhenaidah site

\begin{tabular}{|c|c|c|c|}
\hline Parameter & $\mathrm{HB}$ & PUA & USGA \\
\hline \multicolumn{4}{|c|}{ Rangpur site } \\
\hline Variety & BRRI dhan28 & BRRI dhan28 & BRRI dhan28 \\
\hline Seeding date & 14 Dec 2014 & 14 Dec 2014 & 14 Dec 2014 \\
\hline Transplanting date & 29 Jan 2015 & 29 Jan 2015 & 29 Jan 2015 \\
\hline Seedling age & 45 days & 45 days & 45 days \\
\hline Spacing & $20 \times 20 \mathrm{~cm}$ & $20 \times 20 \mathrm{~cm}$ & $20 \times 20 \mathrm{~cm}$ \\
\hline \multirow[t]{4}{*}{ Basal fertilizer } & TSP@136 kg ha-1 & TSP@136 kg ha-1 & TSP@136 kg ha-1 \\
\hline & MOP@111 kg ha-1 & MOP@111 kg ha-1 & MOP@111 kg ha-1 \\
\hline & Gypsum@111 kg ha-1 & Gypsum@111 kg ha-1 & Gypsum@111 kg ha-1 \\
\hline & $\underline{\text { Zn@7.5 kg ha-1 }}$ & $\underline{\text { Zn@7.5 kg ha-1 }}$ & $\underline{\mathrm{Zn} @ 7.5 \mathrm{~kg} \mathrm{ha}-1}$ \\
\hline Weedicide & Superclean@0.75 kg ha-1 & Superclean@0.75 kg ha-1 & Superclean@0.75 kg ha-1 \\
\hline Application time & 23 Feb 2015 & 1 Feb 2015 & 1 Feb 2015 \\
\hline Weeding & One time & One time & One time \\
\hline Top dressing & Urea $272 \mathrm{~kg} \mathrm{ha}^{-1}$ & Urea $188 \mathrm{~kg} \mathrm{ha}^{-1}$ & Urea $186 \mathrm{~kg} \mathrm{ha}^{-1}$ \\
\hline 1st top dress & Urea 90 kg ha-1 & - & - \\
\hline 2nd top dress & Urea 90 kg ha-1 & - & - \\
\hline 3rd top dress & Urea 92 kg ha-1 & - & - \\
\hline Insecticide & $\begin{array}{l}\text { Virtako one time } \\
\text { @ } 75 \mathrm{~g} \mathrm{ha}^{-1}\end{array}$ & $\begin{array}{l}\text { Virtako one time } \\
@ 75 \mathrm{~g} \mathrm{ha}^{-1}\end{array}$ & $\begin{array}{l}\text { Virtako one time } \\
@ 75 \mathrm{~g} \mathrm{ha}^{-1}\end{array}$ \\
\hline \multirow[t]{3}{*}{ Fungicide } & Nativo one time & Nativo one time & Nativo one time \\
\hline & @ 300 g ha-1 & @ 300 g ha $^{-1}$ & @ $300 \mathrm{~g} \mathrm{ha}^{-1}$ \\
\hline & $\begin{array}{l}\text { Trooper one time } \\
@ 2.25 \mathrm{~kg} \mathrm{ha}^{-1}\end{array}$ & $\begin{array}{l}\text { Trooper one time } \\
@ 2.25 \mathrm{~kg} \mathrm{ha}^{-1}\end{array}$ & $\begin{array}{l}\text { Trooper one time } \\
@ 2.25 \mathrm{~kg} \mathrm{ha}^{-1}\end{array}$ \\
\hline Maturity date & 2 May 2015 & 3 May 2015 & 2 May 2015 \\
\hline \multicolumn{4}{|c|}{ Jhenaidah site } \\
\hline Variety & BRRI dhan28 & BRRI dhan28 & BRRI dhan28 \\
\hline Seeding date & 15 Dec 2014 & 15 Dec 2014 & 15 Dec 2014 \\
\hline Transplanting date & 10 Feb 2015 & 10 Feb 2015 & 10 Feb 15 \\
\hline Seedling age & 56 & 56 & 56 \\
\hline Spacing & $20 \times 20 \mathrm{~cm}$ & $20 \times 20 \mathrm{~cm}$ & $20 \times 20 \mathrm{~cm}$ \\
\hline \multirow[t]{4}{*}{ Basal fertilizer } & TSP@90 kg ha-1 & TSP@90 kg ha-1 & TSP@90 kg ha-1 \\
\hline & MOP@112 kg ha-1 & MOP@112 kg ha-1 & MOP@112 kg ha-1 \\
\hline & Gypsum@90 kg ha-1 & Gypsum@90 kg ha-1 & Gypsum@90 kg ha-1 \\
\hline & $\underline{\mathrm{Zn} @ 7.5 \mathrm{~kg} \mathrm{ha} \mathrm{p}^{-1}}$ & $\underline{\mathrm{Zn} @ 7.5 \mathrm{~kg} \mathrm{ha}{ }^{-1}}$ & $\underline{\mathrm{Zn} @ 7.5 \mathrm{~kg} \mathrm{ha}^{-1}}$ \\
\hline Weedicide & Rifit+Logran@185 g ha-1+ $10 \mathrm{~g} \mathrm{ha}^{-1}$ & Rifit+Logran@185 g ha ${ }^{1}+10 \mathrm{~g} \mathrm{ha}^{-1}$ & $\begin{array}{l}\text { Rifit+Logran@185 g ha-1+ } \\
10 \text { g ha-1 }^{-1}\end{array}$ \\
\hline Application date & 7 Mar 2015 & 13 Feb 2015 & 13 Feb 2015 \\
\hline Weeding & 2 times & One time & One time \\
\hline Top dressing & Urea $272 \mathrm{~kg} \mathrm{ha}^{-1}$ & Urea $187 \mathrm{~kg} \mathrm{ha}^{-1}$ & Urea $186 \mathrm{~kg} \mathrm{ha}^{-1}$ \\
\hline 1st top dress & Urea $90 \mathrm{~kg} \mathrm{ha}^{-1}$ & - & - \\
\hline 2nd top dress & Urea 90 kgha $^{-1}$ & - & - \\
\hline 3rd top dress & Urea 92 kg ha-1 & - & - \\
\hline Insecticide & Virtako one time @ $75 \mathrm{~g} \mathrm{ha}^{-1}$ & $\begin{array}{l}\text { Virtako one time } \\
\text { @ } 75 \mathrm{~g} \mathrm{ha}^{-1}\end{array}$ & Virtako one time @ $75 \mathrm{~g} \mathrm{ha}^{-1}$ \\
\hline Fungicide & $\begin{array}{l}\text { Nativo one time } \\
@ 300 \mathrm{~g} \mathrm{ha}^{-1}\end{array}$ & $\begin{array}{l}\text { Nativo one time } \\
@ 300 \mathrm{~g} \mathrm{ha}^{-1}\end{array}$ & $\begin{array}{l}\text { Nativo one time } \\
@ 300 \mathrm{~g} \mathrm{ha}^{-1}\end{array}$ \\
\hline Maturity date & 13 May 2015 & 15 May 2015 & 14 May 2015 \\
\hline
\end{tabular}

\section{RESULT AND DISCUSSION}

\section{Field capacity}

Field capacity is an important factor for any kind of machine operation. Figure 1 shows that field capacity of PUA and USGA applicator was similar (0.09-0.10 ha $\left.\mathrm{hr}^{-1}\right)$ in both the locations. Field efficiency of PUA and USGA obtained 64-65 and 68-69 percent, respectively. 


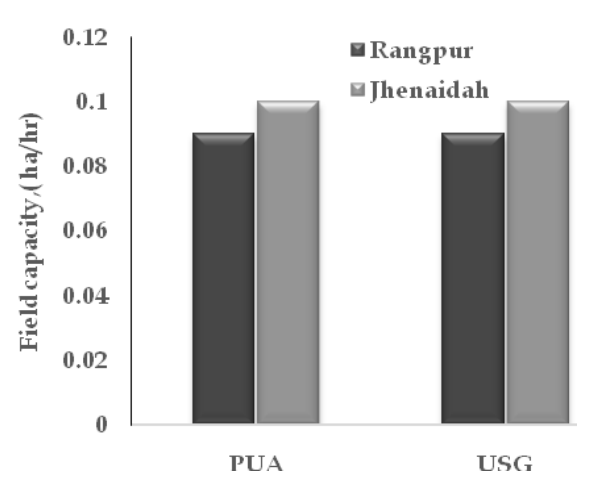

(a)

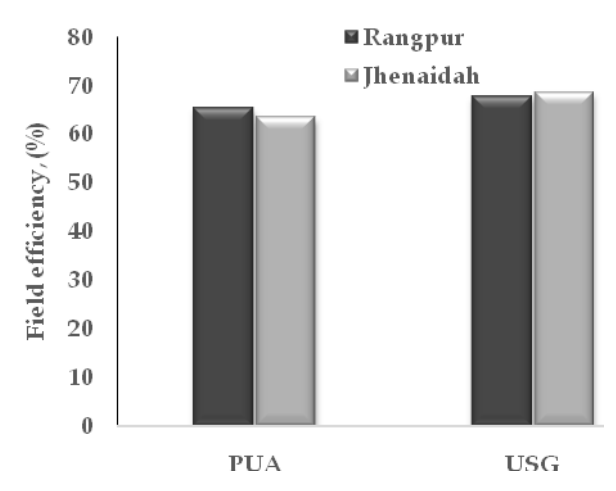

(b)

Fig. 1. Field capacity and efficiency of PUA and USGA

\section{Fertilizer savings}

Traditionally, farmers used $272 \mathrm{~kg} \mathrm{ha}^{-1}$ of urea in the field in three equal splits. Figure 2 shows that 29-32 percent urea fertilizer can be saved by using PUA and USGA.

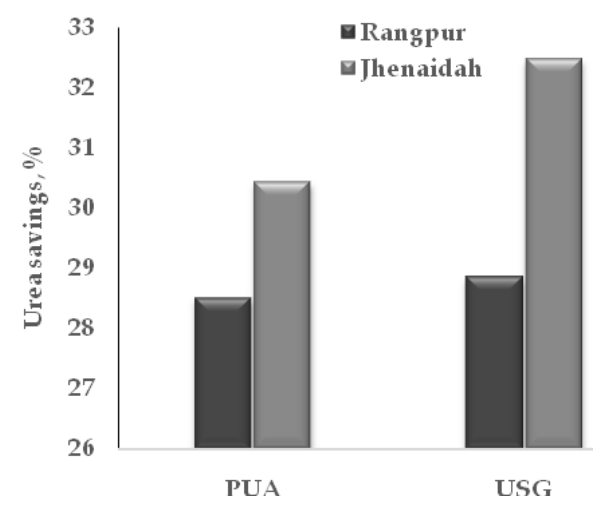

Fig. 2. Fertilizer savings by PUA and USGA

\section{Plant spacing}

In USGA plot, it is mandatory to maintain exact plant to plant spacing and line to line distance to facilitate the operation of applicator as USG needs to be placed adjacent to four consecutive hills for better fertilizer efficacy. Whereas, in PUA plot, it is mandatory to maintain line to line distance of the plants only as prilled urea dispensed adjacent to two lines. Farmers were advised to maintain exact spacing as $20 \times 20 \mathrm{~cm}$ in PUA and USGA plots. Actually, plant to plant spacing depends largely on the skill of the labour. In Rangpur site, plant spacing obtained $24.62 \times 23.30,24.83 \times 22.67$ and $23.74 \times$ $21.73 \mathrm{~cm}$ in HB, PUA and USGA plots, respectively. In Jhenaidah site, plant spacing of $17.97 \times 22.18,18.07 \times 22.14$ and $18.57 \times 21.74 \mathrm{~cm}$ in HB, PUA and USGA plots, respectively. Results on plant spacing were not consistent (Fig. 3). It was observed that more than $80 \%$ of the plant did not maintain the spacing uniformly, which affected the operation of the applicator. Only $20 \%$ plant maintained the uniform spacing. 


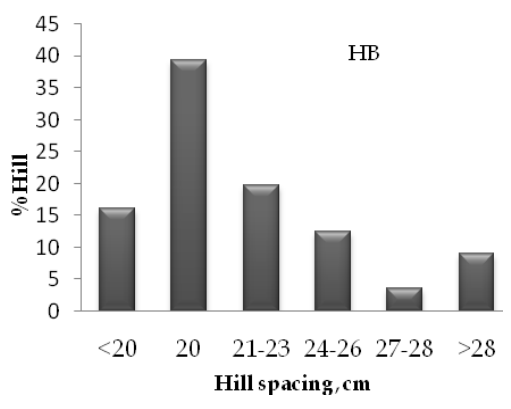

a. Rangpur

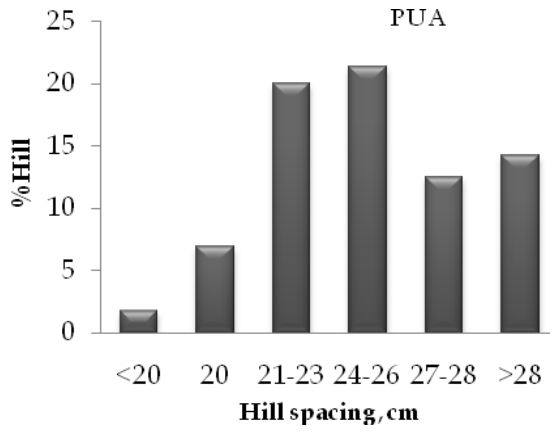

a. Rangpur

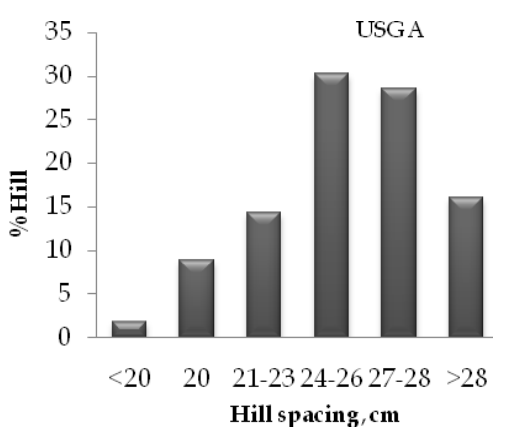

a. Rangpur

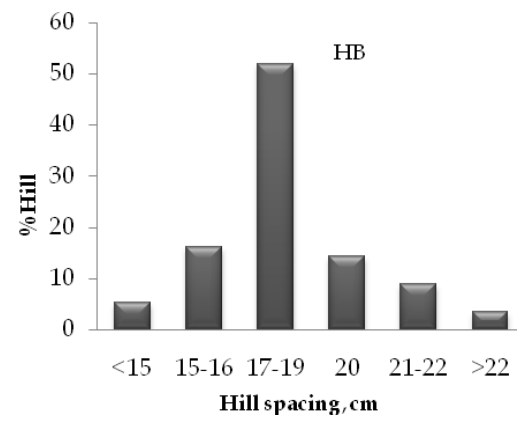

b. Jhenaidah

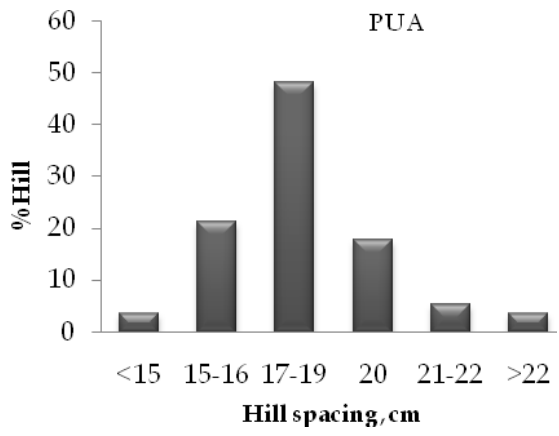

b. Jhenaidah

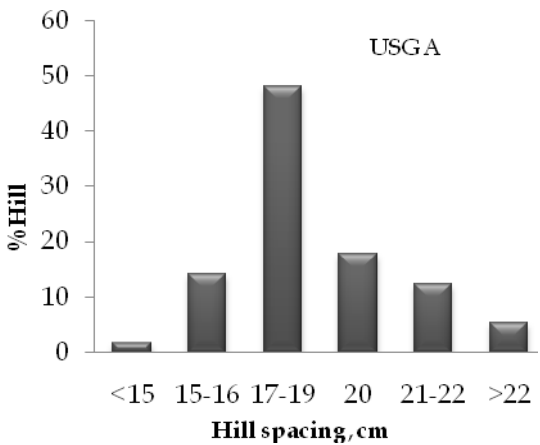

b. Jhenaidah

Fig. 3. Distribution of seedling spacing

\section{Plant population per hill}

Figure 4 shows the effect of management practices at different days after transplanting. Plant population observed similar in both

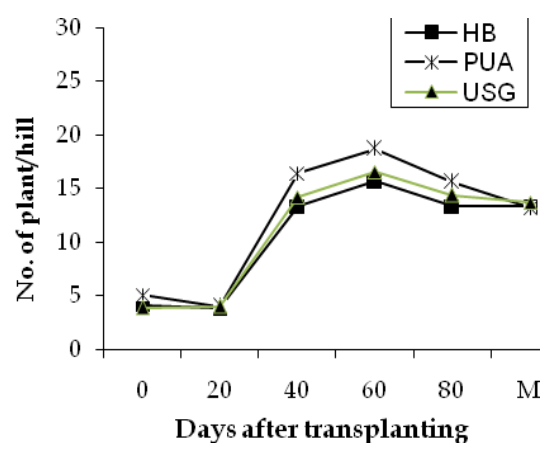

a. Rangpur practices. Plant population increased progressively overtime attaining the highest at 40 DAT. Plant population followed rapid growth from 20 to 40 DAT in three practices.

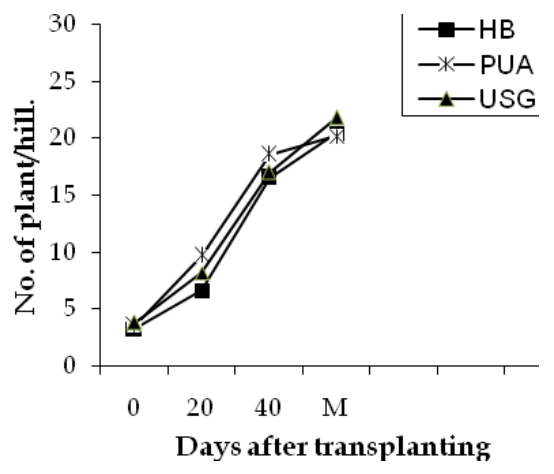

b. Jhenaidah

Fig. 4. Hill density of urea application plot 


\section{Plant height}

Figure 5 shows the effect of urea fertilizer application at different days after transplanting. Plant height observed similar in three practices. Plant height increased

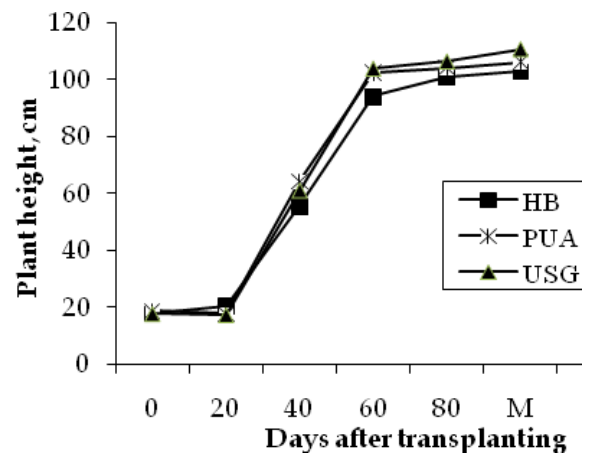

a. Rangpur progressively over time. Plant height followed rapid growth from 20 to 60 DAT in three practices.

Fig. 5. Plant height in both sites

\section{Tillering pattern}

Figure 6 shows the effect of management practices on tillering in both the locations. Tillering pattern behaved similar pattern throughout the production period. Irrespective

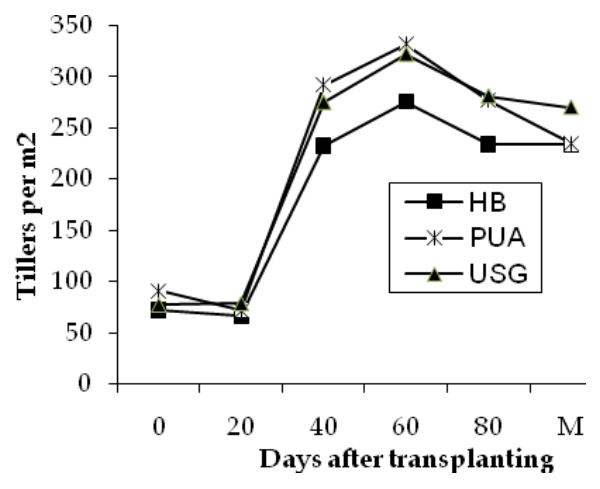

a. Rangpur of the management practices, tillering pattern followed increasing trend. In three practices, the tiller production sharply increased from 20 DAT.

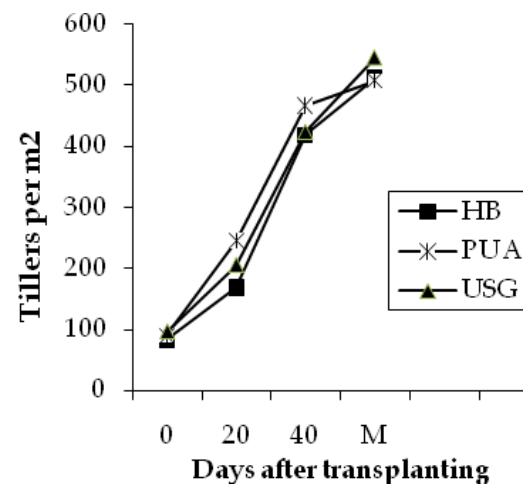

b. Jhenaidah

Fig. 6. Plant population

\section{Grain yield}

Table 2 presents grain yield and yield contributing character, which was statistically analyzed. Irrespective of location, urea application method showed insignificant effect on grain yield. Urea application method showed insignificant effect on panicle intensity, panicle length and 1000-grain mass. Grain yield of all the treatment is lower in Jhenaidah than Rangpur site due to crop damaged by hail storm. Hail storm occurred after maximum tillering stage (on 6 Apr 2015, after 60 days of transplanting) and some crops revived within panicle initiation stage. 
Table 2. Yield and yield contribution character

\begin{tabular}{llcccccc}
\hline Location & Treatment & $\begin{array}{c}\text { Grain } \\
\text { yield, } \\
\text { ha }^{-1}\end{array}$ & Panicle, no. $\mathrm{m}^{-2}$ & $\begin{array}{c}\text { Panicle } \\
\text { length, } \\
\mathrm{cm}\end{array}$ & $\begin{array}{c}\text { Grain, no. } \\
\mathrm{m}^{-2}\end{array}$ & $\begin{array}{c}\text { Sterility, } \\
\%\end{array}$ & $\begin{array}{c}1000- \\
\text { grain } \\
\text { mass }\end{array}$ \\
\hline Rangpur & HB & 5.11 & 209.5 & 20.38 & 21517 & 28.87 & 23.12 \\
& PUA & 5.19 & 220.25 & 21.42 & 18875 & 32.44 & 22.28 \\
& USGA & 5.12 & 240.15 & 21.23 & 24601 & 31.41 & 21.36 \\
Jhenaidah & HB & 4.22 & 383.50 & 18.58 & 31894 & 22.12 & 23.47 \\
& PUA & 4.48 & 345.00 & 18.75 & 21863 & 30.24 & 23.05 \\
& USGA & 4.70 & 365.00 & 18.41 & 30146 & 33.75 & 23.55 \\
CV, \% & & 5.34 & 13.08 & 5.33 & 19.63 & 15.25 & 5.03 \\
LSD 0.05 & L & 0.22 & 33.47 & 0.92 & 4238.6 & $\mathrm{NS}$ & 1.00 \\
& T & NS & NS & NS & 5191.2 & 4.84 & NS \\
& L $\times$ T & NS & NS & NS & NS & NS & NS \\
\hline
\end{tabular}

\section{Labour requirement in crop production}

Table 3 shows the overall labour requirement for the urea application system in two districts. The total labour requirement for rice cultivation observed the highest in Jhenaidah than Rangpur region. It was due to severe weed infestation occurred in Jhenaidah as well as higher labour required removing weeds from the land. Total labour requirement of HB (3.74-4.04 man-hr ha-1) in three splits showed similar to single application of urea by PUA (3.68-4.00 man-hr ha-1) and USGA (3.78-3.97 man-hr ha-1). It can be concluded that PUA and USGA did not reduced the labour requirement in urea fertilizer application.

Table 3. Labour requirement (man-hr ha-1) in urea application method in two locations

\begin{tabular}{|c|c|c|c|c|c|c|}
\hline \multirow{2}{*}{ Activity } & \multicolumn{3}{|c|}{ Rangpur } & \multicolumn{3}{|c|}{ Jhenaidah } \\
\hline & HB & PUA & USG & $\mathrm{HB}$ & PUA & USG \\
\hline Seedbed preparation & 1.97 & 1.98 & 2.01 & 1.59 & 1.56 & 1.59 \\
\hline Seeding & 0.38 & 0.38 & 0.3 & 0.35 & 0.34 & 0.37 \\
\hline Irrigation & 24.01 & 23.97 & 23.94 & 24 & 24.01 & 24.01 \\
\hline Seedling uprooting & 28.96 & 28.97 & 29.02 & 19.98 & 19.67 & 20.01 \\
\hline Subtotal & $\begin{array}{l}55.32 \\
(8.21 \%)\end{array}$ & $\begin{array}{l}55.3 \\
(8.21 \%) \\
\end{array}$ & $\begin{array}{l}55.29 \\
(8.17 \%)\end{array}$ & $\begin{array}{l}45.92 \\
(6.39 \%)\end{array}$ & $\begin{array}{l}\mathbf{4 5 . 5 8} \\
(6.37 \%)\end{array}$ & $\begin{array}{l}45.98 \\
(6.40 \%)\end{array}$ \\
\hline \multicolumn{7}{|c|}{ Land preparation } \\
\hline Tillage & $\begin{array}{l}10.3 \\
(1.53 \%)\end{array}$ & $\begin{array}{l}10.15 \\
(1.51 \%)\end{array}$ & $\begin{array}{l}10.6 \\
(1.57 \%)\end{array}$ & $\begin{array}{l}9.03 \\
(1.26 \%)\end{array}$ & $\begin{array}{l}8.97 \\
(1.25 \%)\end{array}$ & $\begin{array}{l}9.02 \\
(1.26 \%)\end{array}$ \\
\hline Levelling & $\begin{array}{l}5.6 \\
(0.83 \%)\end{array}$ & $\begin{array}{l}5.62 \\
(0.83 \%)\end{array}$ & $\begin{array}{l}5.78 \\
(0.85 \%)\end{array}$ & $\begin{array}{l}2.01 \\
(0.28 \%)\end{array}$ & $\begin{array}{l}2 \\
(0.28 \%)\end{array}$ & $\begin{array}{l}2.03 \\
(0.28 \%)\end{array}$ \\
\hline Transplanting & $\begin{array}{l}147.96 \\
(21.96 \%)\end{array}$ & $\begin{array}{l}148 \\
(21.98 \%)\end{array}$ & $\begin{array}{l}150.52 \\
(22.24 \%)\end{array}$ & $\begin{array}{l}150 \\
(20.89 \%)\end{array}$ & $\begin{array}{l}149.99 \\
(20.96 \%)\end{array}$ & $\begin{array}{l}150.01 \\
(20.89 \%)\end{array}$ \\
\hline Weeding & $\begin{array}{l}99.99 \\
(14.84 \%)\end{array}$ & $\begin{array}{l}99.98 \\
(14.85 \%)\end{array}$ & $\begin{array}{l}99.98 \\
(14.77 \%)\end{array}$ & $\begin{array}{l}170.11 \\
(23.69 \%)\end{array}$ & $\begin{array}{l}170 \\
(23.76 \%)\end{array}$ & $\begin{array}{l}169.96 \\
(23.67 \%)\end{array}$ \\
\hline Insecticide spray & $\begin{array}{l}10.00 \\
(1.48 \%)\end{array}$ & $\begin{array}{l}9.99 \\
(1.48 \%)\end{array}$ & $\begin{array}{l}10.03 \\
(1.48 \%)\end{array}$ & $\begin{array}{l}5.01 \\
(0.70 \%)\end{array}$ & $\begin{array}{l}5.07 \\
(0.71 \%)\end{array}$ & $\begin{array}{l}4.99 \\
(0.70 \%)\end{array}$ \\
\hline Fertilizer application & $\begin{array}{l}3.74 \\
(0.56 \%)\end{array}$ & $\begin{array}{l}3.68 \\
(0.55 \%)\end{array}$ & $\begin{array}{l}3.78 \\
(0.56 \%)\end{array}$ & $\begin{array}{l}4.04 \\
(0.56 \%)\end{array}$ & $\begin{array}{l}4.00 \\
(0.56 \%)\end{array}$ & $\begin{array}{l}3.97 \\
(0.55 \%)\end{array}$ \\
\hline Harvesting & $\begin{array}{l}130.01 \\
(19.30 \%)\end{array}$ & $\begin{array}{l}130.02 \\
(19.31 \%)\end{array}$ & $\begin{array}{l}130.02 \\
(19.21 \%)\end{array}$ & $\begin{array}{l}150 \\
(20.89 \%)\end{array}$ & $\begin{array}{l}149.99 \\
(20.96 \%)\end{array}$ & $\begin{array}{l}150.01 \\
(20.89 \%)\end{array}$ \\
\hline Carrying & $\begin{array}{l}45.02 \\
(6.68 \%)\end{array}$ & $\begin{array}{l}45.00 \\
(6.68 \%)\end{array}$ & $\begin{array}{l}45.04 \\
(6.66 \%)\end{array}$ & $\begin{array}{l}42.00 \\
(5.85 \%)\end{array}$ & $\begin{array}{l}39.87 \\
(5.57 \%)\end{array}$ & $\begin{array}{l}41.98 \\
(5.85 \%)\end{array}$ \\
\hline Threshing & $\begin{array}{l}109.99 \\
(16.33 \%)\end{array}$ & $\begin{array}{l}110.01 \\
(16.34 \%)\end{array}$ & $\begin{array}{l}109.94 \\
(16.25 \%)\end{array}$ & $\begin{array}{l}79.97 \\
(11.14 \%)\end{array}$ & $\begin{array}{l}79.97 \\
(11.18 \%)\end{array}$ & $\begin{array}{l}80.06 \\
(11.15 \%)\end{array}$ \\
\hline Winnowing & $\begin{array}{l}51.99 \\
(7.72 \%)\end{array}$ & $\begin{array}{l}51.97 \\
(7.72 \%)\end{array}$ & $\begin{array}{l}51.96 \\
(7.68 \%)\end{array}$ & $\begin{array}{l}55.98 \\
(7.80 \%)\end{array}$ & $\begin{array}{l}56.03 \\
(7.83 \%)\end{array}$ & $\begin{array}{l}56.00 \\
(7.80 \%)\end{array}$ \\
\hline Total & 673.66 & 673.4 & 676.73 & 718.11 & 715.47 & 717.98 \\
\hline
\end{tabular}




\section{Economic analysis}

Table 4 shows that the item wise costs of crop establishment and total production costs. The data demonstrated that the land preparation, transplanting weeding, harvesting, carrying, threshing and winnowing costs were nearly same for three urea application methods on both the sites. Irrigation cost was the lowest in
Jhenaidah site due to use of canal water of GK project at cheapest price. Therefore, irrigation cost greatly influenced the production cost. Fertilizer costs varied depending upon the urea application method. PUA and USGA dispensed 29-32\% less prilled urea than HB. PUA and USGA reduced the production cost in both the locations.

Table 4. Production costs of urea application methods in Rangpur and Jhenaidah.

\begin{tabular}{|c|c|c|c|}
\hline Activity & HB, Tk ha-1 & PUA, Tk ha-1 & USGA, Tk ha-1 \\
\hline \multicolumn{4}{|c|}{ Rangpur } \\
\hline Seedling raising & 4,063 & 4,063 & 4,063 \\
\hline Land preparation & 6,775 & 6,775 & 6,775 \\
\hline Transplanting & 7,456 & 7,456 & 7,456 \\
\hline Machine rental charge & - & 40 & 40 \\
\hline Urea & 4,624 & 3,424 & 3,483 \\
\hline Basal fertilizer & 4,259 & 4,259 & 4,259 \\
\hline Urea application & 184 & 184 & 184 \\
\hline Insecticide application & 4,620 & 4,620 & 4,620 \\
\hline Weeding & 5,000 & 5,000 & 5,000 \\
\hline Irrigation & 6,500 & 6,500 & 6,500 \\
\hline Harvesting & 6,500 & 6,500 & 6,500 \\
\hline Carrying & 2,250 & 2,250 & 2,250 \\
\hline Threshing & 5,500 & 5,500 & 5,500 \\
\hline Winnowing & 2,600 & 2,600 & 2,600 \\
\hline Subtotal & 60,331 & 59,171 & 59,230 \\
\hline Land value & 20,000 & 20,000 & 20,000 \\
\hline Interest on investment & 2,008 & 1,979 & 1,981 \\
\hline Subtotal & 22,008 & 21,997 & 21,981 \\
\hline Total production cost & 82,339 & 81,150 & 81,211 \\
\hline \multicolumn{4}{|c|}{ Jhenaidah } \\
\hline Seedling raising & 3,530 & 3,530 & 3,530 \\
\hline Land preparation & 7,800 & 7,800 & 7,800 \\
\hline Transplanting & 7,500 & 7,500 & 7,500 \\
\hline Machine rental charge & - & 40 & 40 \\
\hline Urea & 4,624 & 3,216 & 3,305 \\
\hline Basal fertilizer & 4,260 & 4,260 & 4,260 \\
\hline Urea application & 200 & 200 & 200 \\
\hline Insecticide application & 2,920 & 2,920 & 2,920 \\
\hline Weeding & 8,500 & 8,500 & 8,500 \\
\hline Irrigation & 1,500 & 1,500 & 1,500 \\
\hline Harvesting & 7,500 & 7,500 & 7,500 \\
\hline Carrying & 2,080 & 2,080 & 2,080 \\
\hline Threshing & 3,167 & 3,167 & 3,167 \\
\hline Winnowing & 1,937 & 1,937 & 1,937 \\
\hline Subtotal & 55,518 & 54,150 & 54,239 \\
\hline Land value & 20,000 & 20,000 & 20,000 \\
\hline Interest on investment & 1,888 & 1,856 & 1,856 \\
\hline Subtotal & 21,888 & 21,856 & 21,856 \\
\hline Total production cost & 77,406 & 76,006 & 76,095 \\
\hline
\end{tabular}


Effect of urea application methods on total cost, gross return and net return

Table 5 shows the total production cost including all the costs. The gross return was calculated based on the then market price of paddy and straw. The BCR were almost same in all the urea application methods in Rangpur site whereas higher in USG plot in Jhenaidah site.

Table 5. Effect of urea application methods on gross return, net return and benefit cost ratio (BCR) at Rangpur and Jenaidha

\begin{tabular}{|c|c|c|c|c|c|c|}
\hline \multirow[t]{2}{*}{$\begin{array}{l}\text { Treat } \\
\text { ment }\end{array}$} & $\begin{array}{l}\text { Total production } \\
\text { cost, Tk ha-1 }\end{array}$ & $\begin{array}{l}\text { Grain yield } \\
\text { Tk ha-1 }\end{array}$ & $\begin{array}{c}\text { Straw yield } \\
\text { Tk ha-1 }\end{array}$ & $\begin{array}{c}\text { Gross } \\
\text { return, Tk } \\
\text { ha-1 }^{-1}\end{array}$ & $\begin{array}{c}\text { Net return, } \\
\text { Tk ha-1 }\end{array}$ & $\begin{array}{l}\text { Benefit Cost } \\
\text { Ratio (BCR) }\end{array}$ \\
\hline & A & B & C & $\mathrm{D}=\mathrm{B}+\mathrm{C}$ & E & $\mathrm{F}$ \\
\hline \multicolumn{7}{|c|}{ Rangpur } \\
\hline $\mathrm{HB}$ & 82,339 & 83,038 & 11,490 & 94,528 & 12,189 & 1.15 \\
\hline PUA & 81,150 & 84,338 & 11,700 & 96,038 & 14,888 & 1.18 \\
\hline USG & 81,211 & 83,200 & 11,520 & 94,720 & 13,509 & 1.17 \\
\hline \multicolumn{7}{|c|}{ Jhenaidah } \\
\hline $\mathrm{HB}$ & 77,406 & 73,850 & 11,490 & 85,340 & 7,934 & 1.10 \\
\hline PUA & 76,004 & 78,400 & 11,700 & 90,100 & 14,096 & 1.19 \\
\hline USG & 76,095 & 82,250 & 11520 & 93,770 & 17,675 & 1.23 \\
\hline
\end{tabular}

\section{CONCLUSIONS}

It can be concluded that among the nitrogen management options, PUA and USGA saved $29-32 \%$ of prilled urea without sacrificing grain yield whereas labour requirement of $\mathrm{HB}$ in three splits was similar to single application of urea by PUA and USGA.

\section{ACKNOWLEDGEMENT}

The authors acknowledge funding provided by the Bill and Melinda Foundation through the CIMMYT implemented CSISA-II project especially Mr Timothy Russel, CoP, CSISA-BD for the implementation of the project. The author indebted to DrMdShahidul Islam, PSO and Head, Regional Station, BRRI, Rangpur for providing technical support.

\section{REFERENCES}

Amit. 2011. Research on the next generation of fertilizers. IFDC, Presented at the Syngenta Foundation for Sustainable Agriculture, Basel, Switzerland.

BADC (Bangladesh Agricultural Development Corporation). 2011. A leaflet of production technology for SL-8H rice production. Hybrid seed production wing of BADC.

Bhuiyan, N I, M A M Miah and M Ishaque. 1998. Research on USG: Findings and future research areas and recommendations. Paper presented at the national workshop on urea super granule technology (USG), held at BARC, Dhaka, Bangladesh, 25 June 1998.
Bowen, W T, R B Diamand, U Sing and T P Thompson. 2005. Urea deep placement increases yield and saves $\mathrm{N}$ fertilizer in farmer's field in Bangladesh. Rice in life: Scientific perspectives for the 21st century. pp. 369372.

Choudhury, A T M A and Y M Khanif. 2004. Effects of nitrogen and copper fertilization on rice yield and fertilizer nitrogen efficiency: A $15 \mathrm{~N}$ tracer study. Pakistan Journal of Scientific and Industrial Research 47, 50-55.

Choudhury, A T M A and I R Kennedy. 2005. Nitrogen fertilizer losses from rice soils and control of environmental pollution problems. Communications in Soil Science and Plant Analysis 36, 1625-1639.

Gomez, K A and AA Gomez. 1984. Statistical procedures in agricultural research, New York, Chichester, etc.: Wiley, 2nd edition, pp. 680.

Hossen, M A, M D Huda, M S Islam, M G K Bhuiyan, M A Rahman and B C Nath. 2013. Design and development of a manually operated urea supper granule (USG) applicator. Agricultural Mechanization in Asia, Africa and Latin America 44(2):85-91.

Iqbal, S H. 2009. Improvement of the existing USG fertilizer applicator, Department of Agricultural Engineering, Bangabandhu Sheikh Mujibur Rahman Agricultural University, Gazipur, Bangladesh.

NAP. 2009. National agricultural policy report on fertilizer application, Government of the People's Republic of Bangladesh, $\mathrm{p}-20$.

Prasad, R and S K Datta. 1979. Increasing fertilizer Nefficiency in wet land rice. Nitrogen and rice. IRRI, Philippines.

Rahman, M A, AKM S Islam, G K Bhuiyan, M A Hossen, S Paul, M Kamruzzaman and M K Islam. 2014. Design and development of BRRI prilled urea applicator. Proceedings of the BRRI Annual Internal Research Review 2013-14. Bangladesh Rice Research Institute, Gazipur. 